OPEN ACCESS

Edited by:

Martin G. Klotz,

Queens College, The City University of

New York, USA

Reviewed by:

Stefan Lalonde,

European Institute for Marine

Studies/Université de Bretagne,

France

Jesse G. Dillon,

California State University,

Long Beach, USA

*Correspondence:

Wendy F. Smythe

smythew@msu.edu

${ }^{\dagger}$ Present Address:

Wendy F. Smythe,

BEACON Center for the Study of Evolution in Action, Michigan State

University, East Lansing, MI, USA

Specialty section:

This article was submitted to

Microbiological Chemistry and

Geomicrobiology,

a section of the journal

Frontiers in Environmental Science

Received: 07 September 2015

Accepted: 20 May 2016

Published: 08 June 2016

Citation:

Smythe WF, McAllister SM, Hager KW, Hager KR, Tebo BM and Moyer CL

(2016) Silica Biomineralization of Calothrix-Dominated Biofacies from

Queen's Laundry Hot-Spring,

Yellowstone National Park, USA.

Front. Environ. Sci. 4:40.

doi: 10.3389/fenvs.2016.00040

\section{Silica Biomineralization of Calothrix-Dominated Biofacies from Queen's Laundry Hot-Spring, Yellowstone National Park, USA}

\author{
Wendy F. Smythe ${ }^{1 *}$, Sean M. McAllister ${ }^{2}$, Kevin W. Hager ${ }^{3}$, Kyle R. Hager ${ }^{3}$, \\ Bradley M. Tebo ${ }^{1}$ and Craig L. Moyer ${ }^{3}$ \\ ${ }^{1}$ Center for Coastal Margin Observation and Prediction, Institute of Environmental Health, Oregon Health \& Science \\ University, Portland, OR, USA, ${ }^{2}$ School of Marine Science and Policy, University of Delaware, Newark, DE, USA, ${ }^{3}$ Biology \\ Department, Western Washington University, Bellingham, WA, USA
}

Experiments on microorganisms capable of surviving silicification are often conducted to gain a better understanding of the process of silica biomineralization and to gain insights into microbially influenced rock formations and biofabrics like those found in ancient deposits such as the Early Archean Apex Chert formation (Schopf, 1993; House et al., 2000). An ideal microorganism for studying silicification is the large sheathed cyanobacterium Calothrix, which form distinctive organo-sedimentary structures in the low to moderate temperature regions of hydrothermal springs or columnar stromatolitic structures in aquatic systems. Our ability to identify and characterize microfossils from ancient deposits allows us to gain a better understanding of environmental conditions on early Earth. Here we characterized Calothrix-dominated biofacies along the outflow apron of Queen's Laundry Hot-Spring in Yellowstone National Park using microscopy and molecular techniques to examine biofacies morphology and phylogenetic diversity. We found that flow regime and temperature had a profound effect on community composition as identified by the observation of five distinct Calothrix-dominated communities and on biofacies architecture along the outflow apron.

Keywords: geomicrobiology, microfossils, mineral templating, hot-springs, biomineralization

\section{INTRODUCTION}

Precambrian cherts have been found to yield silicified microfossils suggesting that ancient microbial communities present in marine waters and hydrothermal ecosystems became embedded in colloidal amorphous silica and were subsequently entombed and preserved in the fossil record as distinct textures (Westall et al., 1995; House et al., 2000). Characterization of extant hot-spring environments provides us the opportunity to better understand and interpret the paleoenvironment in which ancient biofacies formed, allowing us to take a glimpse into Earth's early environments.

The geology of Yellowstone National Park (YNP) strongly influences the composition of hydrothermal fluids as meteoric waters interact at depth with silica rich acid-intermediate volcanic rock, thereby enriching hydrothermal fluids with dissolved silica (Channing and Butler, 2007). Silica deposits, referred to as sinter, form in and around the hot-spring once hydrothermal fluids 
erupt at the surface. As hydrothermal fluids cool the solubility of amorphous silica is exceeded, e.g., due to changes in $\mathrm{pH}$ or temperature and supersaturation through evaporation, resulting in the polymerization of dissolved silica and subsequent precipitation (White et al., 1956; Rimstidt and Barnes, 1980; Benning et al., 2005; Hugo et al., 2011). Siliceous deposits in YNP can be studied as extant analogs of early Earth allowing for the study of biogenic silica deposition and microfossil formation (Channing and Butler, 2007).

In this study, we describe Calothrix-dominated biofacies composed of microbe-mineral assemblages in which mineral deposition exhibits a specific and unique suite of biological characteristics due to nucleation of minerals onto microbial biofilm/mat surfaces. Mineralized Calothrix-dominated mats heavily influence the fabrics of low- to mid-temperature siliceous sinters forming distinctive hot-spring-associated rock formations (Walter, 1972; Cady and Farmer, 1996; Jones et al., 2001; Konhauser et al., 2001). The distinctive Calothrix biofacies have been instrumental in the interpretation of hot-spring paleoenvironments (Walter et al., 1996; Campbell et al., 2001; Jones and Renaut, 2003; Hugo et al., 2011). Microbial populations in Queen's Laundry Hot-Spring are exposed to circumneutral geothermal groundwater fluids that are saturated with dissolved silica resulting in a series of abiotic silicification reactions (Cady and Farmer, 1996; Benning et al., 2004). Microfossils form as silica minerals nucleate on cell wells and in exopolysaccharides, completely impregnating organic material; this must occur rapidly for cell and mat morphology to remain intact (White et al., 1956).

Previous studies have identified Calothrix-like microstructures from sinter deposits of extinct hot-springs, suggesting that Calothrix biofilms directly influence the biofabric of sinter deposits in extant hot-springs (Walter, 1972; Cady and Farmer, 1996; Jones et al., 2001; Konhauser et al., 2001). Silicification of Calothrix is thought to be a passive process due to the rapid and extreme changes in fluid chemistry as fluids flow from the deep source vent(s) to the shallow outflow apron (Konhauser et al., 2003). Here we characterize microfossil formation from three distinct microenvironments along the outflow apron from Queen's Laundry Hot-spring and show that each of these microenvironments host distinct Calothrix-dominated communities.

\section{Calothrix}

Calothrix, constituents of the Rivulariaceae family, one of the most diverse cyanobacterial lineages, are present in marine, freshwater, and terrestrial environments. However, little is known about their genetic diversity from the natural environment due to the lack of data pertaining to the biodiversity of Calothrix present across habitats (Sihvonen et al., 2007). The filamentous cyanobacterium Calothrix has been observed to occupy the upper 1-2 mm of microbial mats formed in silicadominated hot-springs across YNP (Walter, 1976). Rivulariaceae cyanobacteria such as Calothrix are morphologically complex, possessing specific characteristics that make them unique. These include tapering trichomes and terminal heterocysts which are enclosed in a thick fibrillar sheath of microfibrullar capillaceous structures of exopolysacchaide (EPS) and lipopolysaccharides (LPS) forming large branched molecules that are insoluble in water making them resistant to dehydration (Westall et al., 1995; Hoiczyk, 1998; Whitton, 2002). The multilayered exterior presents mechanical and permeability obstacles for larger molecules making it necessary for alternative transport mechanisms, such as porins, and junctional pore complexes (Hugo et al., 2011). These alternative transport mechanisms may contribute to the silicification of cyanobacteria in hotspring environments, thereby allowing for the formation and preservation of microfossils (Hoiczyk and Hansel, 2000). Monomeric dissolved silica is capable of passing through the outer sheath and accumulating in the extracellular space. Polymerization occurs as dissolved silica concentrations increase, trapping amorphous silica in the extracellular space which eventually leads to cell death and the formation of a microfossil. The growth pattern of these microorganisms directly influences the texture of rock formations in and around the hot-springs (Cady and Farmer, 1996).

Algal and bacterial biofacies composed of amorphous silica have been well-characterized and are known to occur around hot-spring environments in YNP forming structures reminiscent of stromatolites (Walter, 1972). However, we have characterized Calothrix-dominated biofacies that form not only textured sinters that are crudely laminated with wavy surface features similar to the commonly recognized columnar domes, but three distinct biofacies identified as; nodular mats, pustular mats (small domes), and terracette ridges (clusters of contiguous domes).

The actively growing surface of the Calothrix mat becomes encrusted with silica minerals so that filaments are completely entombed in a silica matrix deeper in the mat. The rate of mineralization is dependent on several environmental parameters such as $\mathrm{pH}$, silica activity, temperature, and presence of water (Iler, 1979; Braunstein and Lowe, 1996; Walter et al., 1996). Filaments are oriented in the direction of water flow and become fossilized in their orientation due to rapid silica mineralization entombing filaments and EPS making them appear as bundles of filaments. Once completely entombed in silica the sheath is difficult to differentiate from the silica matrix. Due to their resilience to degradation silicified sheaths are more commonly preserved in the rock record than the internal trichome (Figure 1; Jones et al., 2001).

In this study, we characterize the biofacies and the microbial communities from three distinct Calothrix-dominated mats collected at Queen's Laundry Hot-Spring in YNP. These distinct biofacies were characterized from specimens collected along the temperature gradient of the outflow apron. This was done as a means to better understand the effects temperature and fluid dynamics have on community diversity and the morphology of each distinct biofacies, and to characterize the process of microfossil formation and preservation in the rock record.

\section{Field Site Description}

Queen's Laundry is a member of the Sentinel Meadows Group located in the Lower Geyser Basin of YNP, USA at $44^{\circ} 33^{\prime} 48^{\prime \prime} \mathrm{N}$, $110^{\circ} 52^{\prime} 13^{\prime \prime} \mathrm{W}$. The perimeter of the outflow apron is dominated by the sheathed filamentous cyanobacterium Calothrix, which 


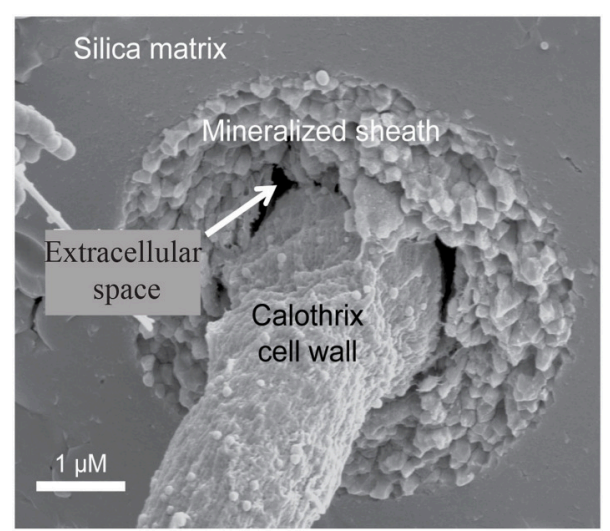

FIGURE 1 | Scanning electron micrograph of an entombed Calothrix filament, whose sheath is completely mineralized with silica allowing the cell to remain intact and preserved.

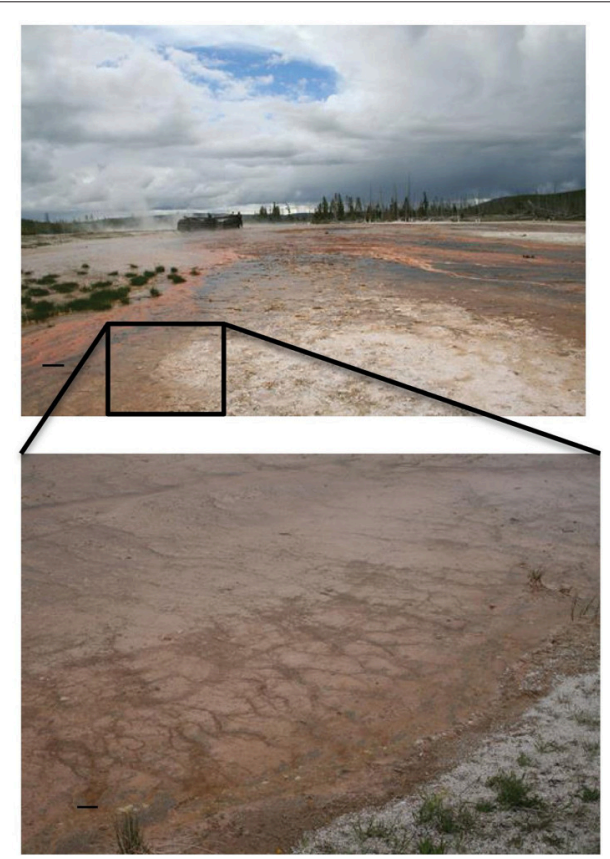

FIGURE 2 | (Top) Overview of the outflow apron, looking from the bottom of the apron. (Bottom) Close-up of Calothrix biofacies on the perimeter of the apron, illustrating nodular and terracette biofacies.

typically populates neutral to alkaline waters between 25 and $50^{\circ} \mathrm{C}$. This gently boiling and surging hot-spring is comprised of a large deep pool with two source vents discharging $\sim 0.6 \mathrm{~m}^{3}$ $\mathrm{h}^{-1}$ of silica-saturated hydrothermal $\left(92^{\circ} \mathrm{C}\right)$ fluids into a narrow stream that meanders around the outflow apron, creating a thermal and $\mathrm{pH}$ gradient (Braunstein and Lowe, 1996; Hugo et al., 2011). The outflow apron broadens into a large braided channeled apron that gently slopes, draining into marshy grasslands (Figure 2). Geochemical data reported by the USGS show that the average concentration of silica from hot-springs in the Lower Geyser Basin is $3.1 \mathrm{mM}$ (McClenskey et al., 2002).
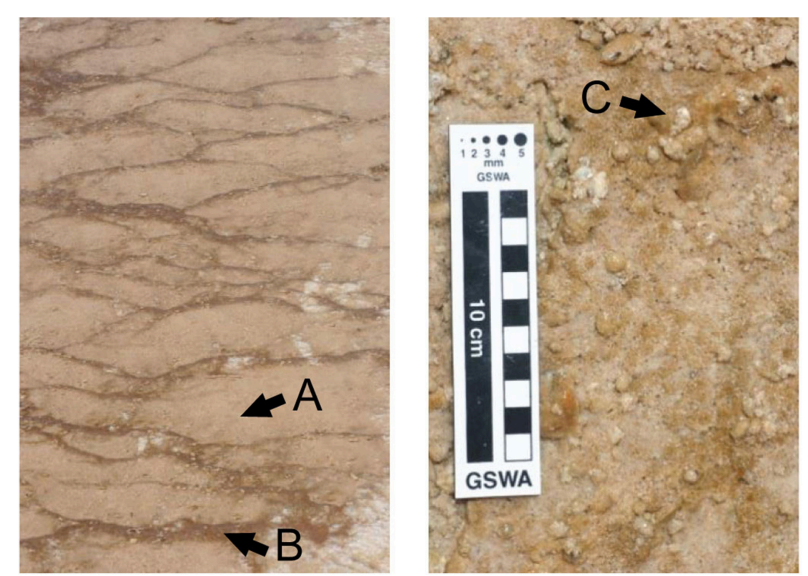

FIGURE 3 | Photo showing three distinct Calothrix biofacies at Queen's Laundry Hot-Spring. (A) Nodular Calothrix mats forming adjacent to the outflow apron in shallow pools. (B) Stratiform terracette mats forming on ridges along the perimeter of the outflow apron. (C) Shallow pools between terracette ridges where pustular mats form.

Biofacies characterized were: (1) nodular mats forming in shallow pools of thermal fluid located at the top and bottom of the outflow apron; temperatures $\sim 25^{\circ} \mathrm{C}$ (Figure 3C), (2) stratiform terracette ridges forming along the length of the outflow apron and wetted by a thin sheet of flowing fluid; temperatures from $50^{\circ} \mathrm{C}$ at the top closest to the source vent to $25^{\circ} \mathrm{C}$ at the bottom (Figure 3B), and (3) pustular mats formed along the length of the outflow apron in shallow gently flowing thermal pools that form between stratiform terracette ridges; temperature of $25-50^{\circ} \mathrm{C}$ from top to bottom of the outflow apron (Figure 3A).

\section{MATERIALS AND METHODS}

\section{Sample Collection and Preparation}

Sinter and microbial mat specimens $(1 \times 1 \mathrm{~cm})$ were collected and immediately fixed in a $3 \%$ gluteraldehyde solution of 0.2 $\mu \mathrm{m}$-filtered spring water for microscopy. Samples collected for molecular analyses were fixed in RNALater (Life Technologies, Grand Island, NY). All samples were stored at $4^{\circ} \mathrm{C}$ while in the field. Prior to microscopic examination specimens were rinsed twice in $0.1 \mathrm{M}$ cacodylate buffer to remove fixative. Calothrix biofacies were examined macroscopically and microscopically, characterizing gross morphology of intact mats and the morphology of individual cells.

\section{Sonication Experiments}

Silica encrusted Calothrix filaments and associated EPS were sonicated in order to remove mineral rinds. Prior to sonication, Calothrix mats exhibited a hirsute appearance from mineralization of the EPS around the filaments. Sonication at $30 \mathrm{~s}$ intervals were increasingly effective until $200 \mathrm{~s}$, when cells began to lyse. 


\section{Stereomicroscope Analysis}

Whole intact Calothrix mats were examined using a Nikon SMZ800 stereoscope; digital images were acquired using a Leica (Wetzlar, Germany) DFC digital camera. Specimens were first examined intact to characterize morphology, surface features, and growth orientation of filaments. Specimens were then sectioned lengthwise, with a scalpel and analyzed in cross-section to characterize the interior of the mat, the average specimen was $5 \mathrm{~mm}$ thick.

\section{Optical Light Microscopy}

Highly mineralized Calothrix mats required removal of mineral rinds in order to observe cellular characteristics using the optical light microscope (OLM). Specimens were prepared for observation by first removing the silica rind encasing filaments and then by removing the top actively growing portion of the Calothrix mat. Sonication of mineralized mats was an effective method of loosening and removing silica rinds that encrusted sheathed filaments. Densely packed filaments cemented in mineral matrices were loosened with the removal of minerals from the sheaths with increasing sonication time. After each
30 s sonication interval the overall mat structure was examined to characterize the integrity of Calothrix filaments using 20X objectives under phase contrast using a Leica (Wetzlar, Germany) DMRX OLM and images were acquired with an Apogee CCD camera.

\section{Scanning Electron Microscopy}

Calothrix mats from each biofacies were examined using a FEI Siron high-resolution scanning electron microscope (HRSEM) equipped with an Energy Dispersive Spectroscopy (EDS) detector (FEI, Hillsboro, OR). Samples were prepared utilizing two dehydration techniques: (1) extensive chemical fixation with osmium tetroxide and dehydration with a graded ethanol series followed by critical point drying, or (2) chemically fixed with a $2 \%$ gluteraldehyde (Fisher, Pittsburg, PA) solution rinsed twice in $0.1 \mathrm{M}$ cacodylate buffer and air-dried in a desiccator. Samples prepared using the first fixation technique were rinsed twice in $0.1 \mathrm{M}$ cacodylate buffer soaking for $10 \mathrm{~min}$ each, post-fixed using a $1 \%$ osmium tetroxide (Fisher, Pittsburg, PA) solution prepared in $0.1 \mathrm{M}$ cacodylate buffer (Fisher, Pittsburg, PA) for $1 \mathrm{~h}$, after which samples were rinsed twice in $0.1 \mathrm{M}$ cacodylate

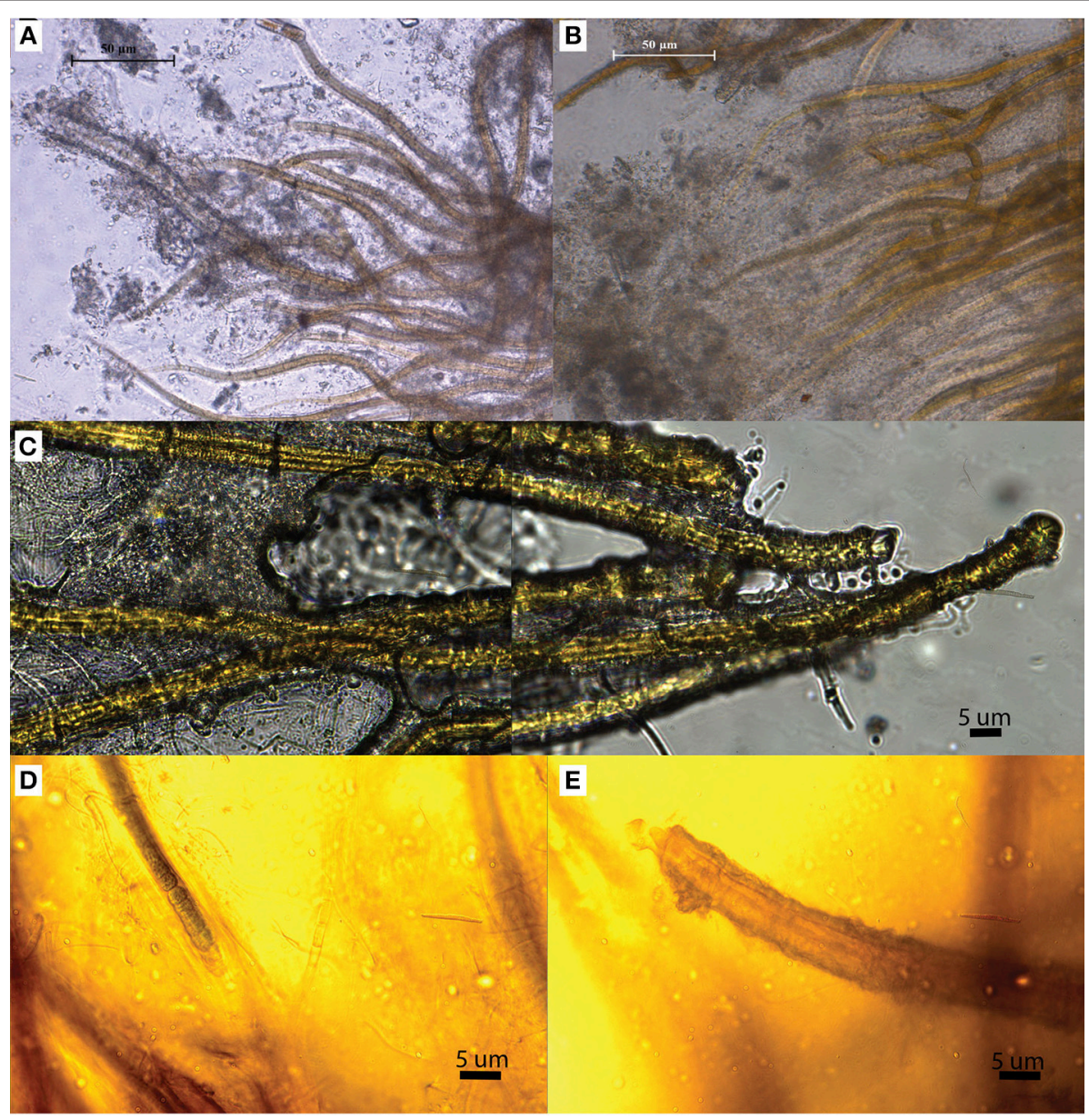

FIGURE 4 | OLM images illustrating the various stages of silicification. (A,B) Illustrate primary (A) and advanced (B) encrustation. (C) Filaments are cemented together in a solid silica matrix illustrating encasement. (D,E) Illustrate entombment, as filaments are not only encrusted in silica but entombed in a solid silica matrix. 


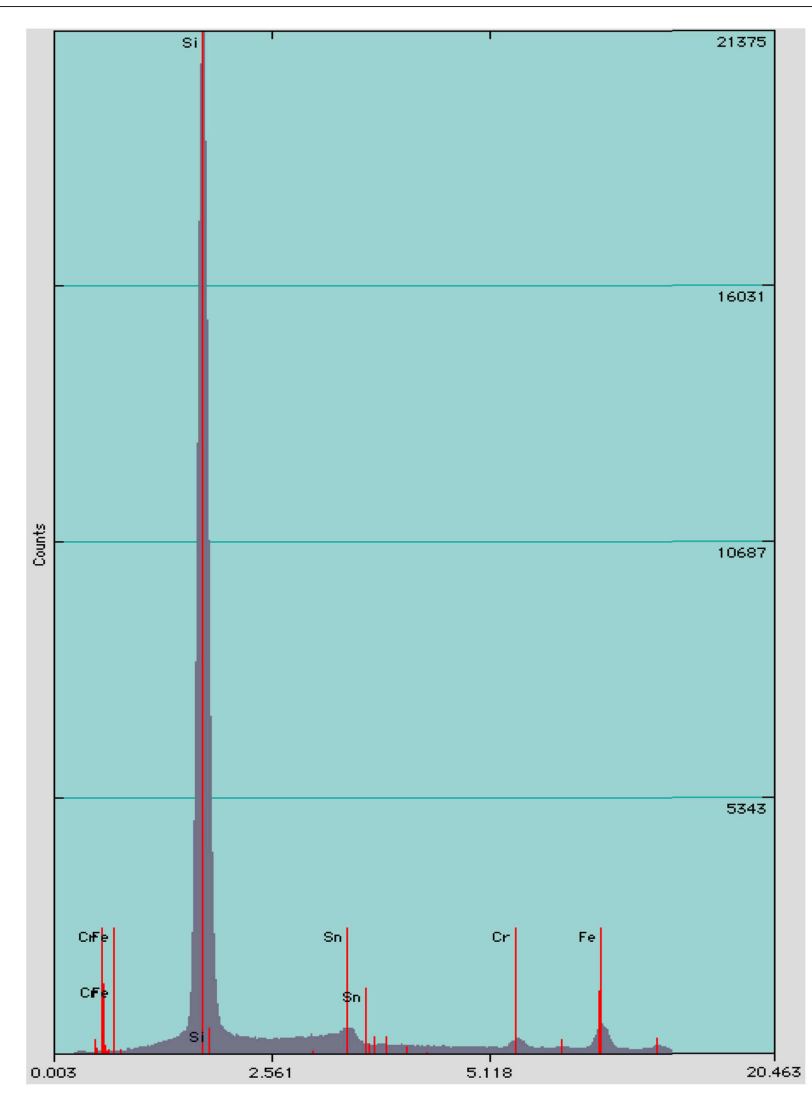

FIGURE 5 | EDS spectrum of minerals formed on Calothrix filaments, shows silicon as the dominant element.

buffer, dehydrated using a graded ethanol series (50, 70, 90, and $100 \%$ ), and then critical point dried. Dehydrated specimens were mounted on aluminum pins and coated with $100 \AA \mathrm{Au}$ Pd.

EDS analysis provides elemental and chemical analysis of a minerals associated with Calothrix filaments. Spectra were collected using $50 \mathrm{kV}$, and visualized using AZtecEnergy analysis software (Oxford Instruments).

\section{Genomic DNA Extraction}

Genomic DNA (gDNA) was extracted from samples using the FastDNA SPIN Kit for Soil (MP Biomedicals, Solon, OH) following the manufacturer's protocol with the modification that the gDNA was eluted into $10 \mathrm{mM}$ Tris at $\mathrm{pH}$. The purity and concentration of gDNA were determined with a Nanodrop ND-1000 spectrophotometer (Thermo Scientific, Wilmington, $\mathrm{DE}$ ) and diluted to $\sim 10 \mathrm{ng} / \mu \mathrm{L}$ for downstream molecular applications.

\section{Community Diversity}

Community diversity of Calothrix biofacies was analyzed using terminal restriction fragment length polymorphism (TRFLP), providing a fingerprint of the community from each biofacies, based on the small subunit ribosomal RNA (SSU rRNA) gene. The methodology used for T-RFLP analysis

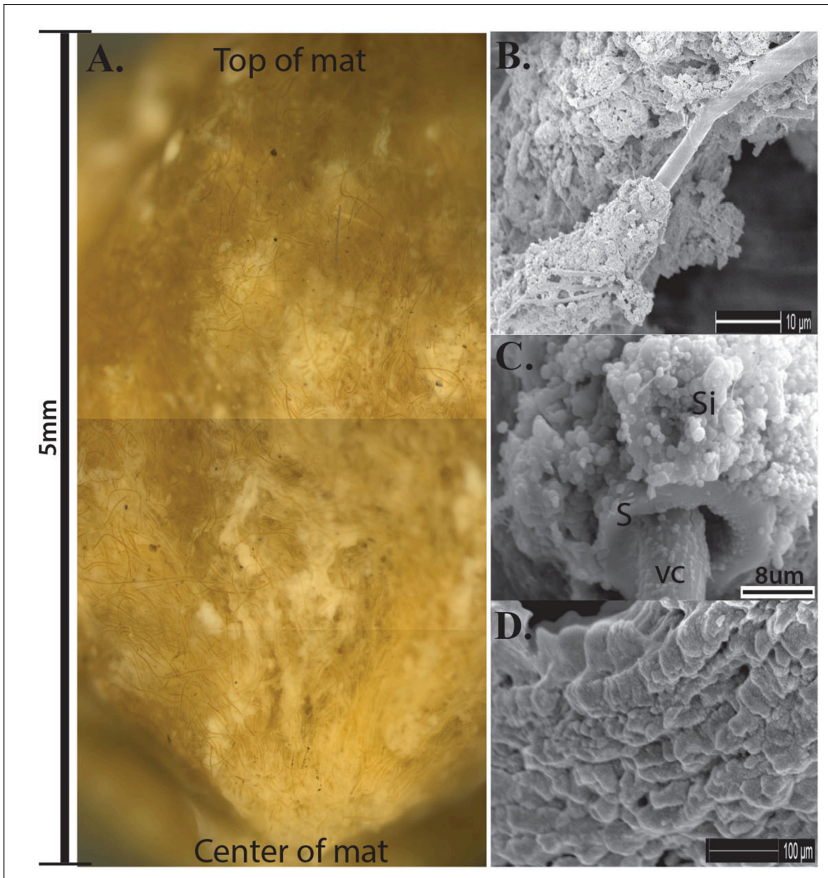

FIGURE 6 | (A) Cross-section of Calothrix nodular mat, scale bar to the left shows the average depth of the mats. Notice filaments radiating from the center of the mat. (B) SEM of Calothrix filament from the top of the mat having very little silica deposition. (C) SEM of filament from the mat center, the sheath (S) is heavily encrusted with amorphous silica (Si), the vegetative cell (VC) is protruding from the sheath. (D) SEM of silicified sheath from the mat bottom. Internal trichomes have degraded with just the mineralized sheath remaining.

has been reported in detail in previous publications (Davis and Moyer, 2008; Rassa et al., 2009; Fleming et al., 2013). This technique accurately resolves populations in microbial communities of low to intermediate richness (Engebretson and Moyer, 2003). Electropherograms are imported into the program BioNumerics (Applied Maths, Austin, TX) where community fingerprints were compared using average Pearson product moment correlation (Häne et al., 1993). Community fingerprints were compared between 50 and 500 base pairs (bp) and the average Pearson product moment correlation coefficient was calculated for cluster analysis by unweighted pair group method with arithmetic mean (UPGMA) combining eight restriction digests (Davis and Moyer, 2008). The primer set used was 68F-FAM (5' 6-FAM - TdNA dNAC ATG CAA GTC GdK dK CG 3') and 1492R (5' dKGdP TAC CTT GTT ACG ACT T $3^{\prime}$ ) with identical conditions as previously reported (Rassa et al., 2009). Three replicate PCR reactions were pooled, desalted using Amicon ${ }^{\circledR}$ Pro Purification System (EMD Millipore, Darmstadt, Germany), and split between eight restriction enzyme treatments using AluI, BstUI, HaeIII, HhaI, HinfI, MboI, MspI, and RsaI (New England BioLabs, Ipswich, MA). Reactions were visualized with an internal LIZ500 (Applied Biosystems, Foster City, CA) size standard by capillary electrophoresis on an ABI 3130xl genetic analyzer (50cm capillary array, POP-6; Life Technologies, Grand Island, NY). 

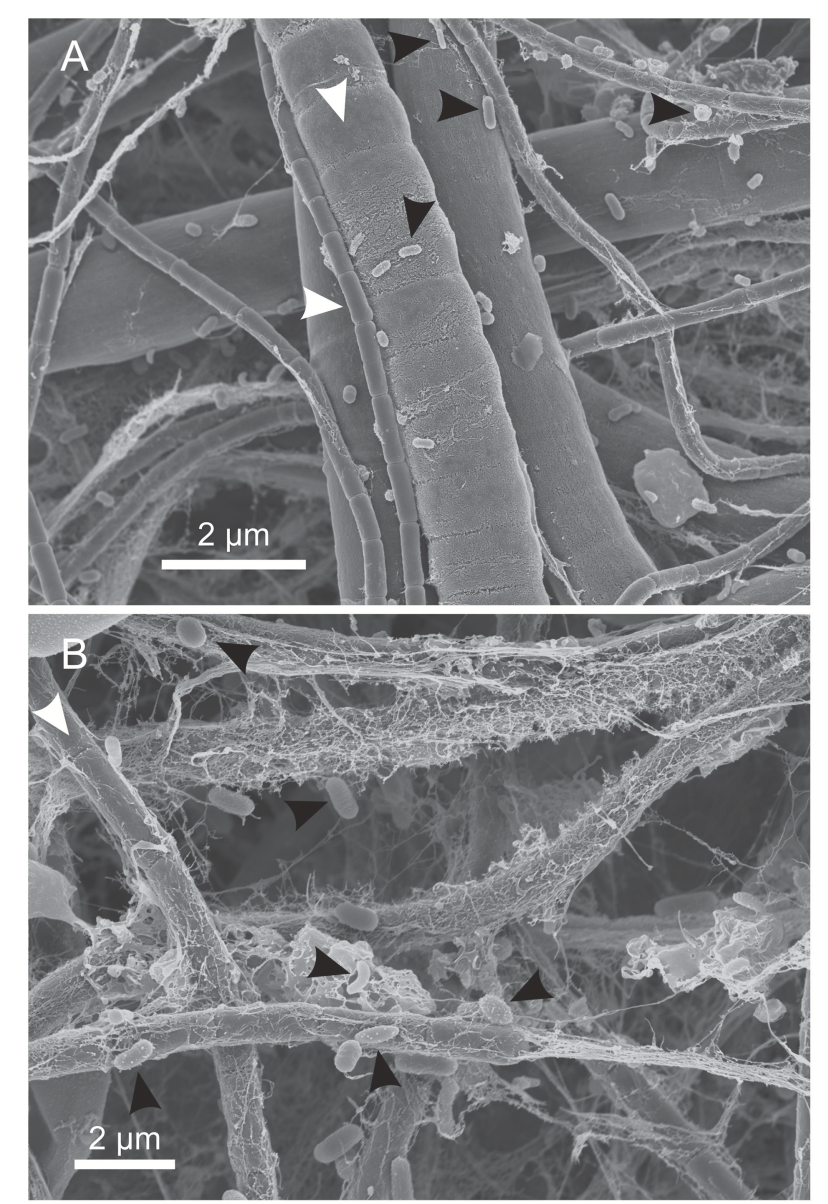

FIGURE 7 | SEM of microorganisms colonizing the surface of Calothrix filaments. (A) Calothrix filament (white arrows) colonized by small rods (black arrows). (B) Calothrix filaments (white arrows) colonized by microorganisms exhibiting several morphotypes (black arrows), including straight and curved rods and cocci. The thin strands around the filaments is dehydrated EPS.

\section{Clone Library}

Five replicate SSU rRNA gene PCR reactions were pooled and cleaned as above, with the modification that the forward primer did not contain a $5^{\prime}$ fluorescent label. Desalted amplicons were cloned with a CloneJET PCR Cloning Kit following manufacturer's instructions (Thermo Fisher Scientific, Waltham, MA). All clones were streaked to isolation and assayed for the correct size fragment using PCR with pJET1.2 forward and reverse primers. Clones were then grown up in Terrific Broth with $100 \mu \mathrm{g}$ mL-1 ampicillin and were sequenced at Beckman Coulter Genomics (Danvers, MA). Operational taxonomic unit (OTU) analysis was initially determined with $5^{\prime}$ reads of the SSU rRNA gene (Tartof and Hobbs, 1987). Sequences were aligned using the ARB-SILVA database with SINA Webaligner (Pruesse et al., 2007), masked, and binned into OTUs based on $97 \%$ minimum similarity. At least one clone from each OTU was chosen for full-length sequencing and checked for chimeras using Pintail (Ashelford et al., 2005) and Mallard (Ashelford et al., 2006). Using unambiguously aligned full-length

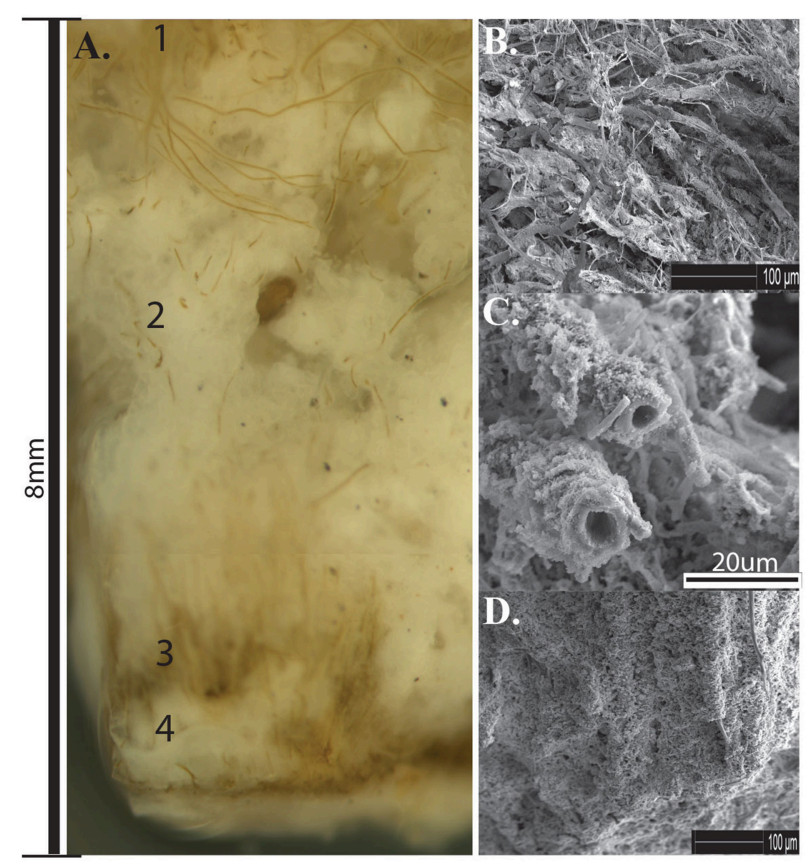

FIGURE 8 | (A) Cross-section of Calothrix pustular mat. (1) Actively growing mat (2) Silica deposition (3) Silicified mat (4) Silica deposition. (B) SEM of silica encrusted Calothrix filaments and EPS from the top of the mat. (C) SEM of silica encrusted filaments from the middle of the mat, filaments eventually become encased in amorphous silica. (D) SEM of filaments cemented together forming a solid biofacies.

sequences, phylogenetic placements according to maximum likelihood methods were calculated using RAxML version 7.2.6 (Stamatakis, 2006) with the General Time Reversible (GTR) model of nucleotide substitution, optimized substitution rates, and GAMMA model of rate heterogeneity; bootstrap values were calculated using a 1000 replicates. Full-length sequences were submitted to the National Center for Biotechnology Information (NCBI), accession numbers KU382114 through KU382143.

\section{Estimating Relative Abundance of Calothrix using T-RFs}

Relative proportions of Calothrix from each of the three biofacies were calculated using restriction maps from the T-RFLP restriction enzymes (Engebretson and Moyer, 2003; Rarnette, 2009). Estimates of community composition were generated in silico from Calothrix and cyanobacterial sequences found from clone library analysis. Upon examining the eight restriction enzymes we found that restriction enzyme BstUI had the most specific identifier signature for Calothrix by comparison of the terminal-restriction fragments (T-RFs). Comparison of T-RFs showed that peaks at $57 \mathrm{bp}$ were shared with the least amount of other cyanobacteria from the Calothrix biofacies.

To estimate the relative abundance of Calothrix within the community all bands between 50 and $500 \mathrm{bp}$ were counted for the BstUI digests. The height of the band representing the 57 bp Calothrix T-RF was divided by the sum of the heights from all the bands in the electropherogram above a $3 \%$ background 

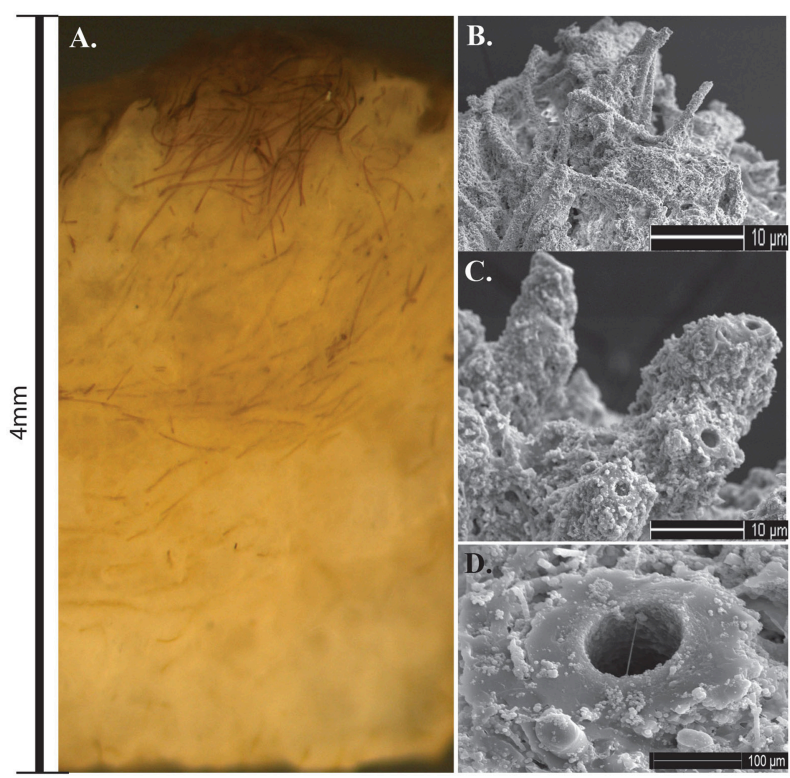

FIGURE 9 | (A) Cross-section of Calothrix terracette mat. Most of the mat is heavily mineralized with amorphous silica with a thin layer of un-mineralized filaments on the surface. (B) SEM of silica encrusted Calothrix filaments from the top of the mat. (C) SEM of filaments becoming entombed in a solid silica matrix. (D) SEM of a preserved sheath from the mat bottom, internal trichomes have degraded with just the sheath remaining

relative fluorescence maximum. This method gave us an estimate of Calothrix relative abundance. Abundance estimated from TRFs is only semi-quantitative. For example, while this method estimated a $76 \%$ abundance of Calothrix sp., clone library analysis found only $47 \%$ Calothrix sp.

\section{RESULTS}

We identified three distinct stages of silicification using microscopy: (1) encrustation, when the sheath of individual filaments is overlain with fragile silica minerals that easily fracture and dissociate when manipulated (Figures 4A,B); (2) encasement, when cells have a rind of silica minerals forming around individual filaments and EPS developing a thick, tough semisolid outer mineral rind (Figure 4C); and (3) entombment of individual filaments occurs when cells are cemented together in a solid silica matrix (Figures 4D,E). EDS analysis of Calothrix biofacies revealed that silicon was the most abundant element in the mineral matrices (Figure 5).

\section{Nodular Calothrix Biofacies}

Nodular Calothrix mats formed loose, spherical nodules on the bottom of shallow pools. Nodular mats were pigmented dark green to brown. The dark coloration is due to the presence of the pigment scytonemin in the sheath and is typically found to be synthesized in environments where cyanobacteria are exposed to intense light and UV irradiation (Ehling-Schulz et al., 1997; Dillon and Castenholz, 2003). Filaments in the nodular mats were oriented vertically from the base of the mat fanning out toward the surface of the mat which was encased in a semi-solid EPSmineral matrix of amorphous silica (Figure 6A). Nodular mats were found growing in shallow pools covering a wide distribution of temperatures between 75.9 and $14.3^{\circ} \mathrm{C}$. Calothrix filaments at the surface of the mat serve as a substrate for colonization by other microorganisms (Figure 7), filaments in the center of the mat had accumulated more silica in their EPS with the outer sheath becoming semi-solid, and filaments at the base of the mat were entombed in amorphous silica with the extensive outer sheath becoming completely fossilized (Figures 6B-D respectively).

\section{Pustular Calothrix Biofacies}

Pustular Calothrix mats formed attached to the bottom of shallow terracette pools along the length of the outflow apron. Mats had an irregular morphology sitting atop a semi-solid core of compacted silica grains, in which filaments grow radially from the core. Pustular mats were dark brown-green pigmented, forming an extensive mat along the bottom of pools (Figure 8A). Calothrix filaments were cemented together in a semi-solid EPS-silica matrix, with the tapered ends of the filament anchored in the underlying sinter and the filament body and terminal heterocyst directed outwards. The surface of the mat had a hirsute appearance from protruding filaments (Figure 8B). The mat was comprised of alternating layers of Calothrix filaments and amorphous silica, with layers alternating between the tapered and broad ends of the filament (Figure 8C). Sinter at the base of the mat contained completely entombed filaments that were oriented vertically throughout the mat perpendicular to the attachment site at the base of the structure (Figure 8D). Pustular mats formed in spring fluids from 61.2 to $7^{\circ} \mathrm{C}$.

\section{Stratiform Calothrix Biofacies}

Stratiform terracette mats formed slightly raised ridges that formed a continuous meandering narrow mat across the width of the ridge. Mats formed along the length of the outflow apron over a broad temperature range, from 62.2 to $8.5^{\circ} \mathrm{C}$. Microscopic observations of cross-sections through terracette mats exposed multiple laminae composed of alternating layers of filaments that have an upward growth and dense silica layers (Figure 9A). Calothrix filaments in the actively growing upper portion of the mat exhibited tan to dark brown pigmentation, filaments were heavily encrusted in a semi-solid silica matrix (Figures 9B,C). Sheaths at the base of the mat were completely entombed and fossilized (Figure 9D).

\section{Community Analyses}

T-RFLP analyses confirmed the presence of Calothrix as the dominant bacterial species (or operational taxonomic unit, OTU) in these biofacies samples, making up on average $43 \%$ of the community by T-RFLP. From clone library analysis, the dominant Calothrix sp. (at $47 \%$ of the community) from that single sample were related to other Calothrix spp. (AY14702930) found across YNP (Dillon and Castenholz, 2003). The next most abundant species was an unclassified cyanobacterium at $12 \%$ of the community. Further, the unclassified cyanobacterium 


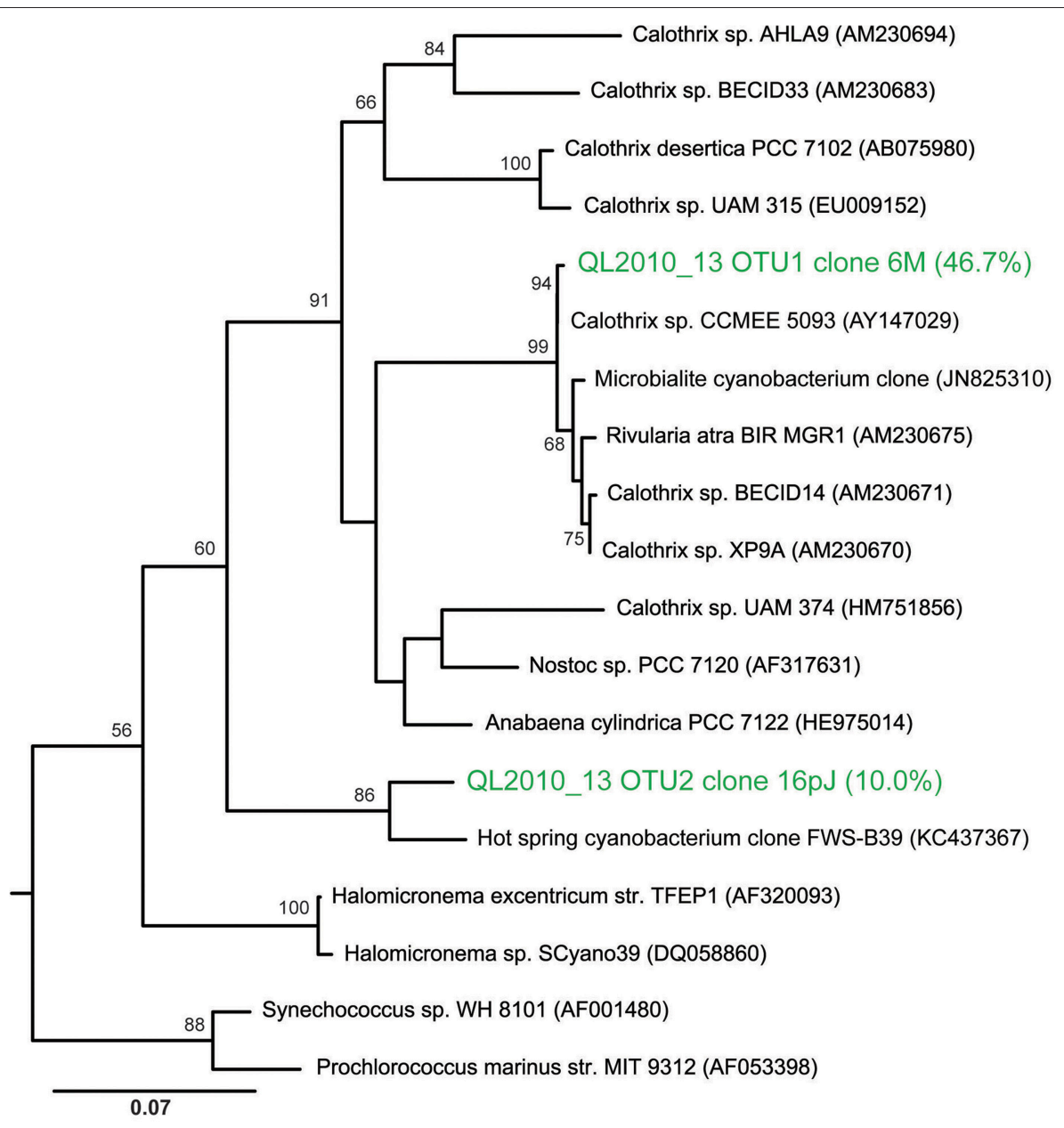

FIGURE 10 | Maximum likelihood phylogenetic tree showing the placement of the two most abundant OTUs from a nodular biofacies (QL2010_13). Calothrix clone 6M13 made up 47\% of the bacterial community, with the next most abundant clone, 16pJET (12\%), being an unclassified cyanobacteria. The tree is rooted using Aquifex pyrophilus.

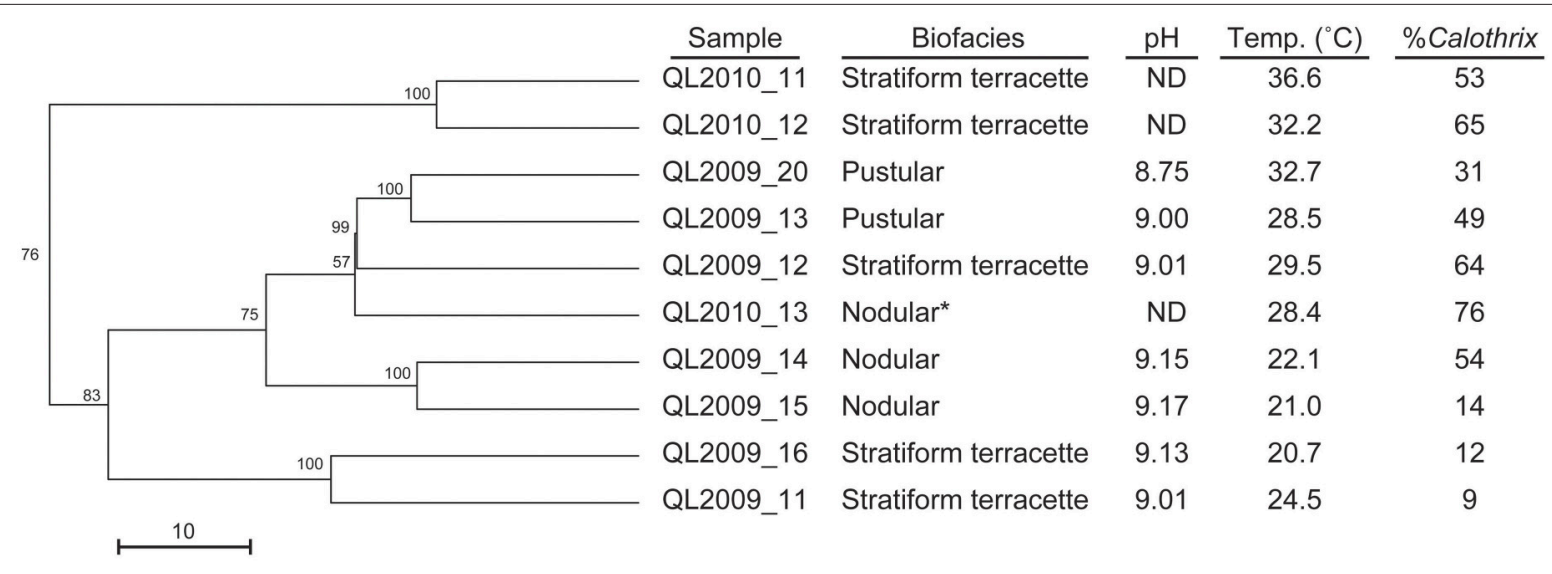

FIGURE 11 | Dendrogram illustrating the cluster analysis of bacterial communities from T-RFLP fingerprints, showing the clustering of our three distinct biofacies at different temperature optima. Starred (*) sample was selected for clone library analysis. 
was most closely related (Figure 10) to an uncultivated clone from a hot-spring in China, with the closest cultivated relative within the GpIV genus of the Cyanobacteria (92\% similar to Halomicronema sp.). The majority of the remaining members of the clone library bacterial community were heterotrophic lineages within the Bacteroidetes at $27 \%$ of the community.

Grouping of biofacies samples by T-RFLP fingerprints showed clustering based primarily by temperature regime and then by biofacies type and the temperature regime and biofacies type (Figure 11). Clustering of samples was also largely dependent on changes in the relative abundance of secondary microbial communities which were identified by their T-RF fingerprint, in agreement with observations made via microscopy (Figure 7). The changes in heterotroph abundance is seen as a decline in Calothrix relative abundance (\%) with temperature in Figure 11. Biofacies samples ranged from 76 to 9\% Calothrix (Figure 10) (Dicksved et al., 2007). Terracette biofacies clustered into three communities based on different sampling temperature niches (high $34^{\circ} \mathrm{C}$, middle $30^{\circ} \mathrm{C}$, and low $22^{\circ} \mathrm{C}$ ). With three clusters of stratiform terracette communities, the diversity of this biofacies type was much greater than the other two biofacies types ( $55 \mathrm{vs.}$ $83 \%$ minimum similarity, respectively).

\section{DISCUSSION}

In YNP Calothrix biofacies appear to be constrained to shallow (few $\mathrm{cm}$ ) regions of the spring across a broad temperature range $\left(7-75.9^{\circ} \mathrm{C}\right)$. The specific environmental conditions (i.e., flow rate and temperature) in which these biofacies form have implications for the interpretation of Calothrix biosignatures preserved in ancient cherts, not unlike those identified by House et al. (2000) in the Gunflint Formation. Previous studies have shown that the extensive fibular sheath around Calothrix filaments plays a significant role in mineral templating as dissolved silica ions nucleate on the sheath and associated EPS and LPS, thereby promoting microfossil formation (Gilbert et al., 2005; Hugo et al., 2011). The addition of reactive side chains to the EPS and LPS challenges the idea of passive mineral nucleation, favoring instead active, directed templating of biogenic minerals (Bhaskar and Bhosle, 2005; Hugo et al., 2011). Directed nucleation of minerals may serve several purposes for the survival of Calothrix in extreme environments. For example the silica rind may offer UV protection, deter predation, and prevent dehydration (Phoenix et al., 2006). In contrast to directed mineral nucleation, spontaneous nucleation occurs as silica-rich hydrothermal fluids erupt to the surface and undergo rapid changes in temperature and $\mathrm{pH}$ (Yee et al., 2003). Our findings suggest that soluble silica ions, similar in molecular structure to water, have the ability to cross through the fibular sheath resulting in the accumulation of silica ions in the extracellular space. The accumulation of silica ions results in spontaneous nucleation, forming silica colloids that become trapped in the extracellular space, further entombing the internal trichomes in silica, and promoting their preservation as microfossils.
In this study we identified and characterized three distinct biofacies along the outflow apron of Queen's Laundry HotSpring, each of which formed distinct textures specific to the flow regime in which they formed. Nodular biofacies formed on the bottom of pools; these biofacies experience little to no fluid motion as they typically form in meanders when fluid discharge from the hot-spring is high. Pustular biofacies form in extremely shallow pools along the outer edge of the outflow apron; mats forming here are attached to the bottom of the pool and experience continual but slow fluid motion. Stratiform terracette biofacies form slightly raised ridges along the outer edge of the outflow apron and experience rapid sheet flow fluid motion. Due to the rapid flow rate, stratiform biofacies are comprised of thin compact layers of Calothrix filaments overlain by relatively massive silica deposits.

We identified and characterized three distinct stages of silicification: encrustation, encasement, and entombment. Close examination of these stages indicate that early silicification and encrustation of Calothrix occurs on the surface of the extensive outer sheath, and with continued silica deposition filaments become encased and eventually cemented together. With continued silica deposition filaments become entombed and advanced mineralization occurs with the infiltration of silica ions in the extracellular space.

Community fingerprinting coupled with clone library construction confirmed that biofacies were Calothrix-dominated. In addition, we found that within the Queen's Laundry HotSpring there was variation in community composition between each distinct biofacies as a result of environmental conditions (i.e., temperature and $\mathrm{pH}$ ). A prior study by Boyd et al. (2012) found that the patchy distribution of phototrophs in diverse ecological niches was a result of adaptions enabling habitation in diverse environments as a function of temperature, $\mathrm{pH}$, and sulfide concentrations. In addition we would suggest that flow regime in which the biofacies form is equally important as it has a profound impact on the delivery of dissolved chemical constituents (e.g., nutrients, carbon, sulfide, etc.), and influences temperature, $\mathrm{pH}$, and morphology of the biofacies.

\section{AUTHOR CONTRIBUTIONS}

WS conceived of the study, with research developed and directed by PIs BT and CM. Samples were collected by WS, SM, KRH, and CM. Morphological analysis was conducted by WS. Molecular analysis was conducted by WS, SM, KRH, KWH, and CM. WS wrote the manuscript, with major contributions from SM and $\mathrm{CM}$, and edits from all coauthors.

\section{ACKNOWLEDGMENTS}

We would like to thank Yellowstone National Park for granting us permission to work within the park. Funding for this project was provided by NSF grant DEB-1311616 to WS, and by Western Washington University's Office of Research and Sponsored Programs and the Fouts Foundation for undergraduate research enhancement to CM. 


\section{REFERENCES}

Ashelford, K. E., Chuzhanova, N. A., Fry, J. C., Jones, A. J., and Weightman, A. J. (2005). At least 1 in $2016 \mathrm{~S}$ rRNA sequence records currently held in public repositories is estimated to contain substantial anomalies. Appl. Environ. Microbiol. 71, 7724-7736. doi: 10.1128/AEM.71.12.7724-7736.2005

Ashelford, K. E., Chuzhanova, N. A., Fry, J. C., Jones, A. J., and Weightman, A. J. (2006). New screening software shows that most recent large 16S rRNA gene clone libraries contain chimeras. Appl. Environ. Microbiol. 72, 5734-5741. doi: 10.1128/aem.00556-06

Benning, L. G., Phoenix, V. R., and Mountain, B. W. (2005). "Biosilicification: the role of cyanobacteria in silica sinter deposition," in SGM Symposium 65: Microorganisms and Earth System-Advances in Geomicrobiology, eds G. M. Gadd, K. T. Semple, and H. M. Lappin-Scott (Staffordshire: Cambridge University Press; Keele University), 131-150.

Benning, L. G., Phoenix, V. R., Yee, N., and Konhauser, K. O. (2004). The dynamics of cyanobacterial Silicification: an infrared micro-spectroscopic investigation. Geochim. Cosmochim. Acta 68, 743-757. doi: 10.1016/S0016-7037(03)00488-5

Bhaskar, P. V., and Bhosle, N. B. (2005). Microbial extracellular polymeric substances in marine biogeochemical processes. Curr. Sci. 88, 45-53.

Boyd, E. S., Fecteau, K. M., Havig, J. R., Shock, E. L., and Peters, J. W. (2012), Modeling the habitat range of phototrophs in Yellowstone National Park: toward the development of a comprehensive fitness landscape. Front. Microbiol. 3:221. doi: $10.3389 /$ fmicb.2012.00221

Braunstein, D. G., and Lowe, D. R. (1996). "The role of hydrodynamics in the structuring and growth of high-temperature $(>73 \mathrm{C})$ siliceous sinter, Yellowstone National Park," in Geological Society of America Annual Meeting, 1996. (Denver, CO).

Cady, S., and Farmer, J. (1996). "Fossilization processes in siliceous thermal springs: trends in preservation along thermal gradients," in Ciba Foundation Symposium No. 202. Evolution of Hydrothermal Ecosystems on Earth and Mars, eds G. R. Bock and J. A. Goode (New York, NY: Wiley \& Sons), 150-173.

Campbell, K. A., Sannazzaro, K., Rodgers, K. A., Herdianita, N. R., and Browne, P. R. L. (2001). Sedimentary facies and mineralogy of the late Pleistocene Umukuri silica sinter, Taupo volcanic zone, New, Zealand. J. Sediment. Res. 71, 728-747. doi: 10.1306/2dc40964-0e47-11d7-8643000102c1865d

Channing, A., and Butler, I. B. (2007). Cryogenic opal-A deposition from Yellowstone hot springs. Earth Planet. Sci. Lett. 257, 121-131. doi: 10.1016/j.epsl.2007.02.026

Davis, R. E., and Moyer, C. L. (2008). Extreme spatial and temporal variability of hydrothermal microbial mat communities along the Mariana Island Arc and southern Mariana back-arc system. J. Geophys. Res. 113, B08S15. doi: 10.1029/2007JB005413

Dicksved, J., Floistrup, H., Bergstrom, A., Rosenquist, M., Pershagen, G., Scheynius, A., et al. (2007). Molecular fingerprinting of the fecal microbiota of children raised according to different lifestyles. Appl. Environ. Microbiol. 73, 2284-2289. doi: 10.1128/AEM.02223-06

Dillon, J. G., and Castenholz, R. W. (2003). The synthesis of the UVscreening pigment, scytonemin, and photosynthetic performance in isolated from closely related natural populations of cyanobacteria (Calothrix sp). Environ. Microbiol. 5, 484-491. doi: 10.1046/j.1462-2920.2003. 00436.x

Ehling-Schulz, M., Bilger, W., and Scherer, S. (1997). UV-B-Induced synthesis of photoprotective pigments and extracellular polysaccharides in the terrestrial cyanobacterium nostoc commune. J. Bacteriol. 179, 1940-1945.

Engebretson, J. J., and Moyer, C. L. (2003). Fidelity of select restriction endonucleases in determining microbial diversity by terminal-restriction fragment length polymorphism. Appl. Environ. Microbiol. 69, 4823-4829. doi: 10.1128/AEM.69.8.4823-4829.2003

Fleming, E. J., Davis, R. E., McAllister, S. M., Chan, C. S., Moyer, C. L., Tebo, B. M., et al. (2013). Hidden in plain sight: discovery of sheath-forming, iron-oxidizing Zeta-proteobacteria at Loihi Seamount, Hawaii, U.S.A. FEMS Microbial. Ecol. 85, 116-127. doi: 10.1111/1574-6941.12104

Gilbert, P. U. P. A., Abrecht, M., and Frazer, B. H. (2005). The OrganicMineral Interface in Biominerals. Rev. Mineral. Soc. Am. 59, 157-185. doi: 10.2138/rmg.2005.59.7

Häne, B. G., Jäger, K., and Drexler, H. G. (1993). The Pearson product-moment correlation coefficient is better suited for identification of DNA fingerprint profiles than band matching algorithms. Electrophoresis 14, 967-972. doi: 10.1002/elps.11501401154

Hoiczyk, E. (1998). Structural and biochemical analysis of the sheath of Phormidium uncinatum. J. Bacteriol. 180, 3923-3932.

Hoiczyk, E., and Hansel, A. (2000). Cyanobacterial cell wall: news from an unusual Prokaryotic envelope. J. Bacteriol. 152, 1191-1199. doi: 10.1128/jb.182.5.11911199.2000

House, C. H., Schopf, J. W., McKeegan, K. D., Coath, C. D., Harrison, T. M., and Stetter, K. O. (2000). Carbon isotopic composition of individual Precambrian microfossils. Geology 28, 707-710. doi: 10.1130/0091-7613(2000)28<707:CICOIP >2.0.CO;2

Hugo, R. C., Cady, S. L., and Smythe, W. F. (2011). The Role of Extracellular polymeric substances in the silicification of Calothrix: evidence from microbial mat communities in hot-springs at Yellowstone National Park, USA. Geomicrobiology 28, 667-675. doi: 10.1080/01490451.2010.511983

Iler, R. K. (1979). The Chemistry of Silica: Solubility, Polymerization, Colloid and Surface Properties and Biochemistry. New York, NY: John Wiley \& Sons Inc.

Jones, B., and Renaut, R. W. (2003). Silicified microbes in a geyser mound: the enigma of low-temperature cyanobacteria in a high-temperature setting. Palaios 18, 87-109. doi: 10.1669/0883-1351(2003)18<87:SMIAGM > 2.0.CO;2

Jones, B., Renaut, R. W., and Rosen, M. R. (2001). Taphonomy of silicified filamentous microbes in modern geothermal sintersimplications for identification. Palaios 16, 580-592. doi: 10.1669/08831351(2001)016<0580:TOSFMI>2.0.CO;2

Konhauser, K. O., Jones, B., Reysenbach, A., and Renaut, R. W. (2003). Hot spring sinters: keys to understanding Earth's earliest life forms. Can. J. Earth Sci. 40, 1713-1724. doi: 10.1139/e03-059

Konhauser, K. O., Phoenix, V. R., Bottrell, S. H., Adams, D. G., and Head, I. M. (2001). Microbial-silica interactions in Icelandic hot spring water: Possible analogues for some Precambrian siliceous stromatolites. Sedimentology 48, 415-433. doi: 10.1046/j.1365-3091.2001.00372.x

McClenskey, R. B., Ball, J. W., Nordstrom, D. K., Holloway, J. M., and Taylor, H. E. (2002). Water-Chemistry Data for Selected Hot Springs, Geysers, and Streams in Yellowstone National Park, Wyoming, 2001-2002. Colorado, CO: USGS, Boulder.

Phoenix, V. R., Bennett, P. C., Engel, A. S., Tyler, S. W., and Ferris, F. G. (2006). Chilean high-altitude hot-spring sinters: a model system for UV screening mechanisms by early Precambrian cyanobacteria. Geobiology 4, 15-28. doi: 10.1111/j.1472-4669.2006.00063.x

Pruesse, E., Quast, C., Knittel, K., Fuchs, B. M., Ludwig, W., Peplies, J., et al. (2007). SILVA: a comprehensive online resource for quality checked and aligned ribosomal RNA sequence data compatible with ARB. Nucleic Acids Res. 35, 7188-7196. doi: 10.1093/nar/gkm864

Rarnette, A. (2009). Quantitative community fingerprinting methods for estimating the abundance of operational taxonomic units in natural microbial communities. Appl. Environ. Microbiol. 75, 2495-2505. doi: 10.1128/AEM.02409-08

Rassa, A. C., McAllister, S. M., Safran, S. A., and Moyer, C. L. (2009). ZetaProteobacteria Dominate the colonization and formation of microbial mats in low-temperature hydrothermal vents at Loihi Seamount, Hawaii. Geomicrobiol. J. 26, 623-638. doi: 10.1080/01490450903263350

Rimstidt, J. D., and Barnes, H. L. (1980). The kinetics of silica-water reactions. Geochim. Cosmochim. Acta 44, 1683-1699.

Schopf, J. W. (1993). Microfossils of the early archean apex chert: new evidence of the antiquity of life. Science 260, 640-646. doi: 10.1126/science.260. 5108.640

Sihvonen, L. M., Lyra, C., Fewer, D. P., Rajaniemi-Wacklin, P., Lehtimäki, J. M., Wahlsten, M., et al. (2007). Strains of the cyanobacterial genera Calothrix and Rivularia isolated from the Baltic Sea display cryptic diversity and are distantly related to Gloeotrichia and Tolypothrix. FEMS Microbiol. Ecol. 61, 74-84. doi: 10.1111/j.1574-6941.2007.00321.x

Stamatakis, A. (2006). RAxML-VI-HPC: maximum likelihood-based phylogenetic analyses with thousands of taxa and mixed models. Bioinformatics 22, 2688-2690. doi: 10.1093/bioinformatics/btl446

Tartof, K. D., and Hobbs, C. A. (1987). Improved media for growing plasmid and cosmid clones. Bethesda Res. Lab Focus 9, 12.

Walter, M. R. (1972). Siliceous algal and bacterial stromatolites in hot spring and geyser effluents of Yellowstone National Park. Science 178, 402-405. 
Walter, M. R. (1976). "Hot-spring sediments in Yellowstone National Park," in Stromatolites, ed M. R. Walter (Amsterdam, Elsevier), 489-498.

Walter, M. R., Des Marais, D. J., Farmer, J. D., and Hinman, N. W. (1996). Lithofacies and biofacies of Mid-Paleozoic thermal spring deposits in the Drummond Basin, Queensland, Australia. Palaios 11, 497-518.

Westall, F., Boni, L., and Guerzoni, E. (1995). The experimental silicification of microorganisms. Paleontology 38, 495-528.

White, D. E., Brannock, W. W., and Murata, K. J. (1956). Silica in hotspring waters. Geochim. Cosmochim. Acta 10, 27-59. doi: 10.1016/00167037(56)90010-2

Whitton, B. A. (2002). "Phylum Cyanophyta (Cyanobacteria)," in The Freshwater Algal Flora of the British Isles. An Identification Guide to Freshwater and Terrestrial Algae, 1st Edn., eds D. M. John, B. A. Whitton, and A. J. Brook (Cambridge: Cambridge University Press), 25-122.
Yee, N., Phoenix, V. R., Konhauser, K. O., Benning, L. G., and Ferris, F. G. (2003) The effect of cyanobacteria on silica precipitation at neutral $\mathrm{pH}$ : implications for bacterial silicification in geothermal hot springs. Chem. Geol. 199, 83-90. doi: 10.1016/S0009-2541(03)00120-7

Conflict of Interest Statement: The authors declare that the research was conducted in the absence of any commercial or financial relationships that could be construed as a potential conflict of interest.

Copyright $\odot 2016$ Smythe, McAllister, Hager, Hager, Tebo and Moyer. This is an open-access article distributed under the terms of the Creative Commons Attribution License (CC BY). The use, distribution or reproduction in other forums is permitted, provided the original author(s) or licensor are credited and that the original publication in this journal is cited, in accordance with accepted academic practice. No use, distribution or reproduction is permitted which does not comply with these terms. 